\title{
Self-Compassion dan Regulasi Emosi pada Remaja
}

\author{
Hanum Hasmarlin, Hirmaningsih \\ Fakultas Psikologi Universitas Islam Negeri Sultan Syarif Kasim Riau \\ email: hanumhasmarlin@gmail.com
}

\begin{abstract}
Abstrak
Artikel INFO

Diterima:11 Sept 2019

Direvisi : 22 Oktb 2019

Disetujui: 04 Des 2019

DOI:

http://dx.doi.org/10.24014/ jp.v14i2.7740

Individu mengalami berbagai perubahan emosi pada masa remaja. Emosi remaja yang cenderung meledak-ledak dan sulit dikendalikan apabila tidak dikelola dengan baik dapat menimbulkan berbagai masalah bagi remaja dan lingkungan sekitarnya. Untuk itu, remaja membutuhkan kemampuan regulasi emosi. Penelitian ini bertujuan untuk menguji secara empirik hubungan self-compassion dengan regulasi emosi pada remaja. Alat ukur yang digunakan adalah skala self-compassion dari Neff (2003) dan skala regulasi emosi dari Gratz dan Roemer (2004). Sampel dalam penelitian ini adalah remaja berstatus siswa SMA berjumlah 398 subjek yang diperoleh dengan melakukan teknik kuota sampling. Data dianalisis menggunakan teknik korelasi product moment. Hasil tersebut menunjukkan bahwa self-compassion memiliki hubungan yang positif dengan regulasi emosi pada remaja. Selain itu, dengan melihat $\mathrm{R}^{2}$ diketahui bahwa self-compassion memberikan sumbangan efektif terhadap regulasi emosi. Berdasarkan aspek-aspek pada self-compassion, diperoleh aspek common humanity memberikan sumbangan efektif paling besar terhadap regulasi emosi. Ditinjau dari perbedaan jenis kelamin, terdapat perbedaan regulasi emosi pada lakilaki dan perempuan. Namun, tidak terdapat perbedaan self-compassion antara laki-laki dan perempuan.
\end{abstract}

Kata kunci: self-compassion, regulasi emosi, remaja.

\section{Self-Compassion and Emotion Regulation In Adolescence}

\begin{abstract}
Individual experience various emotional changes during adolescence. Adolescent's emotions tend to be explosive and difficult to control that can cause various problems for adolescents and the people around. For this reason, adolescents need emotion regulation. The purpose of this study was to find out correlation between self-compassion and emotion regulation on adolescence. The data was collected from self-compassion scale by Neff (2003) and emotion regulation scale by Gratz and Roemer (2004). Sample in this study were 398 students on high school in Pekanbaru who obtained by doing quota sampling. The analysis methods used product moment correlate. Based on the result was noted that there is correlation between self-compassion and emotion regulation with $R$ score 0,494 in significant value $0,000(0,000 \leq 0,05)$. In addition with $R^{2}$ score it is known that self-compassion made an effective contribution of $24.4 \%$ to emotion regulation. Based on aspects of self-compassion, the common humanity aspect obtained the biggest effective contribution to emotion regulation which is $13.68 \%$. Thus, there are difference in emotion regulation between men and women. However, there is no difference in self-compassion between men and women.
\end{abstract}

Keywords: self-compassion, emotion regulation, adolescence.

\section{Pendahuluan}

Masa remaja merupakan salah satu periode dalam perkembangan manusia yang menarik perhatian untuk dibicarakan. Pada masa remaja, individu banyak mengalami berbagai perubahan meliputi perubahan fisiologis maupun psikologis (Berk, 2012). Salah satu perubahan psikologis yang terjadi pada masa remaja adalah perubahan sosioemosional, dimana remaja memiliki ketegangan emosi yang cukup tinggi. Hal ini dijelaskan oleh Hall (dalam Berk, 2012) bahwa remaja umumnya mengalami konflik yang kompleks, sehingga masa remaja sering dikenal dengan masa "storm and stress".

Berk (2012) menjelaskan bahwa pada masa remaja, individu akan mulai memiliki ketertarikan pada lawan jenis, minat karir dan eksplorasi identitas. Menurut Neff dan McGehee (2010) hal tersebut menimbulkan tekanan tersendiri bagi remaja, seperti 
tekanan yang dirasakan atas kinerja akademis, kebutuhan untuk menjadi populer, keinginan untuk diterima, merasa cocok dalam suatu kelompok sosial yang tepat, permasalahan hubungan dengan lawan jenis dan body image. Keadaan yang demikian, ditambah dengan perubahan emosional yang dirasakan remaja, perubahan minat, peran dan kondisi lingkungan yang menimbulkan tekanan sosial, membuat ketegangan emosi pada remaja semakin bertambah tinggi.

Hasan (2006) menjelaskan bahwa emosi memiliki tingkatan intensitas tertentu. Satu peristiwa yang sama dapat membuat banyak individu mengeluarkan respon emosional yang berbeda-beda intensitasnya. Intensitas emosi yang terlalu tinggi dapat membuat individu kehilangan kontrol. Hasil penelitian yang dilakukan oleh Geriadi (2017) pada siswa SMA 3 Salatiga yang mengalami putus cinta diperoleh bahwa sebanyak $61.67 \%$ siswa memiliki regulasi emosi pada kategori rendah. Penelitian Yuniar dan Darmawati (2017) pada remaja SMAN di Kota Bandung diperoleh sebanyak $48,3 \%$ regulasi emosi remaja berada pada kategori rendah. Hasil penelitian Estefan dan Wijaya (2014) juga menjelaskan bahwa remaja yang memiliki pengelolaan emosi yang rendah salah satunya ditandai dengan menyakiti dirinya sendiri. Cara ini diyakini dapat memberikan ketenangan sesaat serta mampu membebaskan remaja dari rasa sakit secara psikologis yang dialaminya. Ini senada dengan pendapat Gratz dan Roemer (2008) yang menjelaskan bahwa ketidakmampuan remaja dalam mengelola emosi berhubungan dengan deliberate self-harm.

Permasalahan dan tekanan yang ada di dalam kehidupan sehari-hari pada hakikatnya merupakan suatu batu loncatan untuk membuat remaja menjadi lebih dewasa dalam bertindak. Hurlock (2011) menjelaskan remaja memiliki pengelolaan emosi yang baik jika mampu menilai situasi secara kritis terlebih dahulu sebelum bereaksi secara emosional. Penelitian yang dilakukan Ubaidillah (2014) menemukan emosi yang dialami remaja dapat mempengaruhi pengambilan keputusan pada remaja. Kemampuan pengelolaan emosi yang rendah membuat remaja tidak berpikir panjang akan konsekuensi dari sebuah keputusan, sehingga remaja mengambil keputusan yang tidak tepat.

Kemampuan untuk dapat mengelola emosi bagi remaja juga berhubungan dengan kebiasaan mengalami berbagai masalah yang menekan dirinya seperti kecemasan dan depresi. Bila individu mampu mengelola emosi negatifnya (kesedihan, ketakutan dan kemarahan), remaja tersebut memiliki daya tahan untuk tidak terkena kecemasan dan depresi (Gross, Richards \& John, 2006; Santrock, 2007). Hal ini diperkuat oleh hasil penelitian yang dilakukan oleh Betts, Gullone dan Allen (2009) yang menemukan kemampuan mengelola emosi yang baik merupakan salah satu faktor yang dapat mengurangi risiko depresi pada remaja. Hasil penelitian yang dilakukan oleh Putri, Uyun dan Sulistyarini (2017) juga menemukan pengelolaan emosi yang baik dapat memberikan kontribusi dalam kesehatan psikologis individu.

Stres, depresi, dan emosi negatif seperti sedih, marah, kecewa, dan putus asa tidak bisa dihindari secara penuh. Untuk menghadapi semua situasi yang menekan dan meminimalisasi dampak negatifnya secara psikologis, remaja membutuhkan regulasi emosi. Regulasi emosi yang dimaksud tidak melarang remaja merasakan kondisi emosional yang dialami, melainkan intensitas dan ekspresi emosinya diatur agar tidak sampai merugikan diri sendiri ataupun orang lain.

Permasalahan yang berkaitan dengan regulasi emosi dikaitkan dengan selfcompassion. Hal ini dikarenakan peneliti mengasumsikan bahwa untuk mengatasi emosi-emosi negatif, remaja terlebih dahulu harus memberikan kepedulian dan pemahaman pada diri sendiri saat menghadapi permasalahan dan tekanan yang terjadi. Memiliki sikap belas kasih terhadap diri sendiri (self-compassion) bisa menjadi awal dalam mengatasi emosi-emosi negatif yang dirasakan (Diedrich, Grant, Hofmann, Hiller \& Berking, 2014; Sirois, Kitner \& Hirsch, 2015). Hal ini sejalan dengan pendapat Neff (2003) bahwa self-compassion dapat dipandang sebagai strategi pengaturan emosional yang berguna, khususnya coping dan regulasi emosi, yakni perasaan menyakitkan atau menyedihkan tidak dihindari, namun justru diadakan dalam kesadaran dengan kebaikan (self-kindness), rasa kemanusiaan bersama (common humanity) dan kesadaran penuh perhatian (mindfulness).

Remaja yang memiliki self-compassion akan terhindar dari stres dan depresi karena remaja akan menerima kenyataan dengan pemahaman dan kepedulian pada diri sendiri yang sangat membantu dalam menghadapi tekanan serta dapat memicu emotional 
coping skills yang lebih baik, seperti menjadi lebih jelas mengenai perasaan diri, dapat memahami emosi dan kemampuan untuk memperbaiki keadaan emosi negatif (Neff, 2012).

Berdasarkan uraian di atas, hipotesis dalam penelitian ini adalah ada hubungan positif antara self-compassion dengan regulasi emosi pada remaja. Semakin tinggi self-compassion maka semakin tinggi regulasi emosi pada remaja. Demikian juga sebaliknya, semakin rendah self-compassion, maka semakin rendah regulasi emosi pada remaja.

\section{Regulasi Emosi}

Gratz dan Roemer (2004) menjelaskan bahwa regulasi emosi mencakup upaya untuk penerimaan emosi, kemampuan untuk mengendalikan perilaku impulsif dan kemampuan untuk menggunakan strategi regulasi emosi sesuai situasi secara fleksibel. Gross (1998) menyatakan bahwa regulasi emosi mengacu pada proses-proses yang dilakukan individu untuk mempengaruhi emosi yang dimiliki, kapan individu memilikinya, bagaimana individu mengalami dan mengekspresikan emosi tersebut. Gyurak, Gross dan Etkin (2011) menjelaskan konstruk regulasi emosi dengan penekanan pada proses eksplisit dan implisit. Regulasi emosi secara eksplisit sebagai proses yang memerlukan upaya sadar untuk inisiasi dan menuntut beberapa tingkat pemantauan selama implementasi, dan terkait dengan beberapa tingkat wawasan dan kesadaran. Regulasi emosi secara implisit diyakini dibangkitkan secara otomatis oleh stimulus itu sendiri dan berjalan sampai selesai tanpa pemantauan dan dapat terjadi tanpa wawasan dan kesadaran.

Thompson (1994) mendefinisikan regulasi emosi sebagai proses intrinsik (pengaruh regulasi pada perasaan individu) dan ekstrinsik (pengaruh regulasi pada lingkungan) yang bertanggung jawab memonitor, mengevaluasi dan memodifikasi reaksi emosi secara intensif dan khusus untuk mencapai suatu tujuan. Gross dan Thompson (2007) menyatakan bahwa regulasi emosi adalah strategi yang dilakukan secara sadar ataupun tidak sadar untuk mempertahankan, memperkuat atau mengurangi satu atau lebih aspek dari respon emosi yaitu pengalaman emosi dan perilaku. Individu yang memiliki regulasi emosi dapat mempertahankan atau meningkatkan emosi yang dirasakannya baik positif maupun negatif.

Berdasarkan uraian di atas dapat disimpulkan bahwa regulasi emosi adalah suatu proses yang mengatur perasaan, reaksi fisiologis, kognisi dan respon emosi yang dapat mengontrol perilaku untuk mencapai suatu tujuan yang sesuai dengan tuntutan situasional.

Gratz dan Roemer (2004) menjelaskan bahwa ada empat aspek yang digunakan untuk menentukan kemampuan regulasi emosi individu yaitu: pertama, acceptance of emotional response (penerimaan emosi). Merupakan kemampuan individu untuk menerima suatu peristiwa yang menimbulkan emosi negatif dan tidak malu merasakan emosi tersebut ketika menghadapi permasalahan.

Kedua, strategies to emotion regulation (strategi regulasi emosi) yaitu keyakinan individu untuk dapat mengatasi suatu masalah, memiliki kemampuan untuk menemukan suatu cara yang dapat mengurangi emosi negatif dan dapat dengan cepat menenangkan diri kembali setelah merasakan emosi yang berlebihan. Keyakinan bahwa tidak ada keterbatasan dalam mengelola emosi secara efektif ketika dihadapkan pada situasi dengan emosi negatif.

Ketiga, engaging in goal directed behavior (keterlibatan perilaku bertujuan) merupakan kemampuan individu untuk tidak terpengaruh oleh emosi negatif yang dirasakannya sehingga dapat tetap berkonsentrasi, berpikir dan melakukan sesuatu dengan baik. Keempat, control emotional responses (kontrol respon emosi) yaitu kemampuan individu untuk dapat mengontrol emosi yang dirasakannya dan respon emosi yang ditampilkan (respon fisiologis, tingkah laku dan nada suara), sehingga individu tidak akan merasakan emosi yang berlebihan dan menunjukkan respon emosi yang tepat.

\section{Self-Compassion}

Neff (2003) menjelaskan bahwa selfcompassion adalah proses pemahaman tanpa kritik terhadap penderitaan, kegagalan atau ketidakmampuan diri dengan cara memahami bahwa hal tersebut merupakan bagian dari pengalaman sebagai manusia pada umumnya. Stuntzner (2014) menjelaskan bahwa self-compassion adalah area yang mulai muncul dalam penelitian sebagai sarana untuk meningkatkan fungsi pribadi, mental, emosional dan sebagai agen yang berguna dalam mengurangi pikiran dan perasaan negatif. 
Germer (2009) menjelaskan bahwa self-compassion merupakan kemampuan merasakan perasaan dan kemurahan hati yang berkembang dari penerimaan terhadap diri sendiri, secara emosional dan kognitif atas pengalaman diri dan kesadaran untuk tidak menghindar atas pengalaman yang tidak menyenangkan. Penerimaan secara emosional dan kognitif ini juga memungkinkan individu untuk menerima kekurangan diri serta dapat menghadapi situasi-situasi yang terjadi di luar kendali individu.

Berdasarkan uraian di atas, dapat disimpulkan bahwa self-compassion adalah proses pemahaman pada peristiwa yang menyakitkan, mengecewakan, dan menyedihkan pada individu tanpa kritik terhadap penderitaan, kegagalan atau ketidakmampuan diri dengan cara memahami bahwa hal tersebut merupakan bagian dari pengalaman sebagai manusia pada umumnya yang menimbulkan ketenangan dalam menghadapi permasalahan.

Neff (2003) menjelaskan bahwa ada tiga aspek dalam self-compassion, yaitu: pertama, self-kindness, kemampuan untuk memahami diri ketika individu memiliki kekurangan ataupun merasakan penderitaan dalam hidupnya. Sehingga komponen ini menerangkan seberapa jauh individu dapat memahami, memaknai kegagalannya dan tidak mengkritik diri atas peristiwa menyakitkan yang dialami. Kedua, common humanity adalah individu mampu melihat kegagalan sebagai sesuatu yang wajar dan dialami oleh setiap manusia sehingga tidak perlu menyalahkan diri sendiri. Ketiga, mindfulness yaitu kesadaran penuh atas situasi saat ini serta mampu menyeimbangkan pikiran dalam situasi yang menekan. Artinya, individu mampu melihat segala sesuatu yang terjadi dalam keadaan yang sebenar-benarnya tanpa dilebih-lebihkan ataupun dikurang-kurangkan.

\section{Metode Penelitian}

\section{Subjek}

Populasi pada penelitian ini adalah siswa/i SMAN 3 Pekanbaru, SMAN 11 Pekanbaru, SMAN 12 Pekanbaru, SMAS Tri Bakti Pekanbaru, SMAS YLPI Pekanbaru, dan SMAS Muhammadiyah 1 Pekanbaru yang berjumlah 4262 orang. Sampel yang digunakan sebanyak 398 subjek yang terdiri dari kelas X, XI dan XII dari masingmasing sekolah. Teknik pengambilan sampel yang digunakan dalam penelitian ini adalah nonprobability sampling dengan menggunakan kuota sampling (Sugiyono, 2016).

\section{Pengukuran}

Pengumpulan data dalam penelitian ini menggunakan skala self-compassion berdasarkan aspek yang dikemukakan oleh Neff (2003) yaitu kebaikan pada diri sendiri (self-kindness), rasa kemanusiaan bersama (common humanity) dan kesadaran penuh perhatian (mindfulness). Skala regulasi emosi berdasarkan aspek yang dikemukakan oleh Gratz dan Roemer (2004) yaitu acceptance of emotional response (penerimaan emosi), strategies to emotion regulation (strategi regulasi emosi), engaging in goal directed behavior (keterlibatan perilaku bertujuan) dan control emotional responses (respon kontrol emosi).

Sebelum alat ukur digunakan untuk penelitian terlebih dahulu dilakukan try out terhadap 140 remaja. Dari hasil try out diperoleh kefisien reliabilitas untuk skala regulasi emosi adalah sebesar 0,82 . Sedangkan skala selfcompassion memperoleh koefisien reliabilitas sebesar 0,83. Untuk menganalisis data menggunakan teknik analisis data korelasi product moment.

\section{Hasil}

Berdasarkan hasil korelasi product moment diperoleh bahwa terdapat hubungan positif self-compassion dengan regulasi emosi yang artinya, semakin tinggi self-compassion maka semakin baik regulasi emosi pada remaja. Demikian juga sebaliknya, semakin rendah self-compassion, maka semakin buruk regulasi emosi pada remaja $\left(r=0,494 ; R^{2}=\right.$ $0,24 ; p=0,000)$. Dengan demikian hipotesis penelitian diterima.

Berdasarkan analisis data juga diketahui bahwa sampel penelitian didominasi dengan tingkat self-compassion pada kategori tinggi yaitu dengan jumlah 234 subjek (58\%). Sedangkan yang paling dominan kedua berada pada kategori sedang dengan 103 subjek (26\%). Maka dapat diartikan bahwa sebagian besar remaja memiliki selfcompassion yang tinggi. Sedangkan untuk variabel regulasi emosi, sampel penelitian didominasi dengan tingkat regulasi emosi pada kategori sedang yaitu berjumlah 196 subjek (49\%). Maka dapat diartikan bahwa sebagian besar remaja memiliki regulasi emosi yang cukup baik. 
Tabel 1. Hasil Uji Korelasi Aspek Self-Compassion Terhadap Regulasi Emosi

\begin{tabular}{lcc}
\hline & Regulasi Emosi & Sumbangan Efektif Total \\
\hline Self-Kindness & $8.74 \%$ & $24,4 \%$ \\
Common Humanity & $13.68 \%$ & \\
Mindfulness & 1,99 & \\
\hline
\end{tabular}

Tabel 1 menunjukkan bahwa terdapat perbedaan pada setiap aspek self-compassion terhadap regulasi emosi. Aspek common humanity memberikan pengaruh paling besar pada regulasi emosi sebesar $13.68 \%$, aspek self-kindness sebesar $8.74 \%$ dan pengaruh yang paling kecil adalah mindfulness sebesar $1.99 \%$. Hal ini menunjukkan bahwa kemampuan remaja dalam melihat kegagalan serta pengalaman yang negatif sebagai suatu hal yang wajar dan merupakan hal yang dialami setiap manusia memberikan sumbangan efektif yang besar terhadap regulasi emosi pada remaja.

Tabel 2. Uji Perbedaan Ditinjau dari Jenis Kelamin

\begin{tabular}{|c|c|c|c|c|}
\hline Variabel & JK & Mean & Sig. & Ket. \\
\hline \multirow{2}{*}{$S C$} & PR & 64,27 & \multirow{2}{*}{0,909} & \multirow{2}{*}{ Tidak Ada Perbedaan } \\
\hline & LK & 64,36 & & \\
\hline \multirow{2}{*}{ RE } & PR & 41,88 & 0,000 & \multirow{2}{*}{ Ada Perbedaan } \\
\hline & LK & 44,43 & & \\
\hline
\end{tabular}

Berdasarkan tabel 2 diperoleh nilai signifikansi sebesar $0,909 \quad(p>0.05)$ yang artinya varians antara remaja laki-laki dan perempuan tidak memiliki perbedaan yang signifikan pada variabel self-compassion. Hal ini juga terlihat pada nilai mean yang hampir sama pada perempuan $(\mathrm{M}=64.27)$ dan lakilaki $(\mathrm{M}=64.36)$. Sedangkan hasil analisis uji perbedaan regulasi emosi diperoleh signifikansi sebesar $0,000 \quad(p<0,05)$. Hal ini menunjukkan ada perbedaan regulasi emosi ditinjau dari jenis kelamin, yakni laki-laki lebih mampu untuk mengelola emosi yang dimiliki dibandingkan perempuan.

\section{Pembahasan}

Berdasarkan hasil analisis data uji product moment dapat diketahui bahwa ada hubungan positif antara self-compassion dengan regulasi emosi pada remaja. Artinya semakin tinggi self-compassion yang dimiliki remaja, maka semakin baik pula pengelolaan emosi yang dimiliki remaja. Sebaliknya, semakin rendah self-compassion, maka semakin buruk pula pengelolaan emosi pada remaja. Germer (2009) mengemukakan bahwa self-compassion berhubungan dengan kepuasan hidup, regulasi emosi yang lebih baik, rendahnya tingkat depresi dan rendahnya rasa cemas. Hal ini senada juga dengan penelitian Septiyani dan Novitasari (2017) bahwa terdapat hubungan positif antara self-compassion dengan kompetensi emosi.

Self-compassion bisa menjadi awal dalam mengatasi segala emosi-emosi negatif yang dirasakan. Remaja yang memiliki self-compassion mampu melibatkan diri dengan baik saat menghadapi tekanan dan permasalahan (Neff, 2003). Misalnya, ketika remaja mengalami kegagalan atau memiliki permasalahan, remaja yang memiliki selfcompassion cenderung memperlakukan diri sendiri dengan kebaikan, perhatian, dan kepedulian. Remaja menghadapi masalah dan kekurangan tanpa mengkritik diri sendiri, sehingga dapat melakukan apa yang diperlukan untuk membantu dirinya. Allen dan Leary (2010) menjelaskan memperlakukan diri sendiri dengan baik dilakukan dengan cara memberi istirahat pada diri secara emosional atau terlibat dalam tindakan mental kebaikan, seperti self-talk yang positif, berlapang dada dan memaafkan. Dengan tindakan tersebut, remaja dapat merasakan segala sesuatu tanpa menghakimi diri sendiri sehingga membuat remaja dapat lebih menerima peristiwa yang menimbulkan emosi negatif dan tidak cenderung meledak-ledak saat mengalami emosi (Gratz \& Roemer, 2004).

Hal ini ditandai oleh meningkatnya pengaruh positif, seperti penerimaan dan penilaian positif, pemulihan lebih cepat, reaktivitas lebih rendah terhadap stres dan berhubungan negatif dengan strategi 
penanggulangan yang meningkatkan pengaruh negatif, seperti menyalahkan diri sendiri (Finlay-Jones, 2017). Penerimaan yang meningkat, pengaruh positif yang lebih besar dan pengaruh negatif yang lebih rendah yang ditimbulkan oleh self-compassion dapat memobilisasi sumber daya yang lebih besar untuk mengatur emosi dengan cara yang baik.

Remaja yang memiliki self-compassion akan mampu menerima bahwa pengalaman yang menyakitkan dan kegagalan adalah bagian dari pengalaman manusia pada umumnya (Neff, 2003). Saat menghadapi masalah, remaja menyadari bahwa ia tidak sendirian dalam mengalami pengalaman yang menyakitkan sehingga remaja dapat mengurangi perasaan terisolasi (Neff, 2012). Sedangkan, ketika remaja mengganggap bahwa kehidupan orang lain sempurna dan kehidupannya tidak memadai maka remaja menjadi tenggelam dalam masalahnya sendiri dan lupa bahwa orang lain memiliki masalah yang sama. Remaja mengabaikan interkoneksi dengan orang lain (social connectedness), dan merasa bahwa ia adalah satu-satunya di dunia yang sedang menderita. Arti penting interkoneksi dengan orang lain (social connectedness) dapat membantu remaja untuk mengurangi reaksi emosional negatif sehingga remaja tidak akan memikirkan secara terus menerus kejadian yang menimbulkan emosi negatif. Sebagaimana yang dijelaskan Seppala (2013) bahwa tekanan psikologis yang dialami oleh individu dengan koneksi sosial rendah menunjukkan keterampilan regulasi emosi yang tidak memadai.

Remaja yang memiliki self-compassion juga memiliki kesadaran penuh perhatian yang melibatkan pengambilan perspektif yang seimbang, dari situasi yang dialami sehingga remaja tidak terbawa emosi (Neff, 2003). Ketika dihadapkan pada permasalahan dan penderitaan, remaja tidak cenderung memikirkan negatif situasi dan tidak terlalu terfokus dalam emosi. Kesadaran penuh perhatian memungkinkan remaja untuk mendapatkan kejelasan perspektif, dan keseimbangan emosional yang lebih besar. Hal ini memungkinkan remaja untuk menemukan suatu cara dalam mengurangi emosi negatif sehingga dapat mengendalikan respon emosional dan tingkah lakunya (Gratz \& Roemer, 2004).

Berdasarkan hasil penelitian, diketahui bahwa mayoritas remaja memiliki tingkat self-compassion yang berada pada kategori tinggi. Hal ini menunjukkan bahwa remaja telah mampu memperlakukan dirinya dengan kepedulian saat mengalami emosi negatif, dan memiliki kesadaran penuh atas situasi yang dialaminya sehingga remaja tidak akan memikirkan secara terus menerus (ruminasi) pengalaman yang menimbulkan emosi negatif. Sebagaimana yang dijelaskan Neff (2003) individu yang rendah dalam selfcompassion lebih mungkin untuk menanggapi stresor dengan cara self-critical, self-isolating, dan over-identified.

Neff (2003) berasumsi bahwa tingkat selfcompassion pada masa remaja lebih rendah dibandingkan dengan periode kehidupan yang lain. Sedangkan berdasarkan hasil penelitian diperoleh tingkat self-compassion pada remaja berada pada kategori tinggi. Hasil penelitian Neff, Pisitsungkagarn dan Hsieh (2008) menemukan bahwa orang-orang Asia memiliki tingkat self-compassion yang lebih tinggi dibandingkan orang Barat. Orang-orang dalam budaya kolektivis Asia memiliki konsep diri yang saling bergantung yang menekankan perhatian dengan hubungan antarpribadi, memperhatikan orang lain, dan memiliki kesesuaian sosial, sedangkan orang-orang dalam budaya individualistik Barat memiliki konsep diri independen yang menekankan fokus pada otonomi, kebutuhan pribadi, dan keunikan individu. Karena self-compassion menuntut pengakuan akan common humanity (sifat manusiawi) dan rasa keterhubungan yang sama, dapat dijelaskan bahwa selfcompassion lebih tinggi dalam budaya yang menekankan rasa yang saling bergantung (interdependen) daripada independen.

Hasil penelitian juga menunjukkan bahwa regulasi emosi yang dimiliki remaja yang menjadi subjek dalam penelitian ini berada pada kategori sedang. Artinya, kemampuan mengatur emosi pada remaja cukup baik yaitu cukup mampu menerima emosi sehingga menampilkan emosi dengan tepat. Sebagaimana pendapat Hwang (2006) bahwa proses regulasi emosi yang unik pada individu merupakan pengaturan pengalaman emosional dalam pencapaian keinginan sosial sehingga diperoleh respon utama yang tepat secara fisik dan psikologis terhadap permintaan intrinsik (pengaruh regulasi pada perasaan individu) dan ekstrinsik (pengaruh regulasi pada lingkungan).

Pada penelitian ini juga menunjukkan bahwa tidak ada perbedaan tingkat selfcompassion jika ditinjau dari perbedaan jenis 
kelamin. Hasil penelitian ini berbeda dengan penelitian yang telah dilakukan oleh Yarnell, Stafford, Neff, Reilly, Knox dan Mullarkey (2015) yang menunjukkan bahwa terdapat perbedaan jenis kelamin yang mempengaruhi tingkat self-compassion. Tidak adanya perbedaanself-compassionantaraperempuan dan laki-laki bisa dikarenakan attachment yang dimiliki oleh subjek penelitian. Perspektif perkembangan menyoroti peran hubungan secure attachment dalam pengembangan self-compassion (Gilbert \& Procter, 2006; Neff \& McGehee, 2010). Dari perspektif ini, individu menginternalisasi pengalaman hubungan hangat, penerimaan, dan memvalidasi hubungan attachment dari waktu ke waktu, yang memfasilitasi kapasitas untuk menjadi baik, memelihara, dan memahami terhadap diri sendiri. Sebaliknya, individu yang dibesarkan di lingkungan yang lalai, kasar, atau yang memiliki hubungan yang tidak dapat diprediksi dengan figur kelekatan awal cenderung untuk mengembangkan cara yang keras dan kritis untuk berhubungan dengan diri sendiri.

Sementara itu, pada hasil penelitian ini diketahui adanya perbedaan regulasi emosi antara perempuan dan laki-laki, yang menunjukkan bahwa regulasi emosi lakilaki lebih baik dibandingkan perempuan. Hasil ini sesuai dengan penelitian Gross dan John (2003) bahwa terdapat perbedaan jenis kelamin dalam meregulasi emosi. Brody dan Hall (dalam Lewis, Jones, \& Barret, 2008) menjelaskan bahwa laki-laki lebih menggunakan strategi pengaturan emosi pemecahan masalah, perilaku, dan eksternalisasi lebih dari yang dilakukan perempuan, seperti mengambil langkah aktif, dan terlibat dalam kegiatan fisik seperti olahraga. Sedangkan perempuan menggunakan lebih banyak strategi dukungan sosial; internalisasi strategi, seperti menyalahkan diri sendiri dan strategi yang berfokus pada emosi, seperti merenung, terdiri dari perhatian yang terfokus secara pasif pada pengaruh negatif daripada mengambil langkah aktif.

Hasil penelitian yang dilakukan Simon dan Nath (2004) juga menemukan bahwa laki-laki dan perempuan berbeda dalam mengekspresikan emosi baik verbal maupun non verbal sesuai dengan jenis kelaminnya. Perbedaan jenis kelamin dalam pengekspresian emosi dihubungkan dengan perbedaan dalam tujuan laki-laki dan perempuanmengontrolemosinya. Perempuan lebih mengekspresikan emosi untuk menjaga hubungan interpersonal serta membuat perempuan tampak lemah dan tidak berdaya. Sedangkan laki-laki lebih mengekspresikan marah dan bangga untuk mempertahankan dan menunjukkan dominasi. Sehingga, dapat disimpulkan bahwa perempuan lebih dapat melakukan regulasi terhadap emosi marah, penghinaan dan jijik, sedangkan laki-laki pada emosi takut, sedih dan cemas (Matsumoto, Takeuchi, Andayani, Kouznetsova \& Krupp, 1998).

\section{Kesimpulan}

Berdasarkan hasil analisis dapat disimpulkan bahwa terdapat hubungan positif antara self-compassion dan regulasi emosi pada remaja. Dengan kata lain, tinggi rendahnya self-compassion berkaitan dengan tingkat regulasi emosi remaja. Selain itu ditemukan bahwa ada perbedaan tingkat regulasi emosi antara remaja perempuan dan laki-laki. Hal ini menunjukkan bahwa regulasi emosi laki-laki lebih tinggi dibandingkan remaja perempuan. Sementara variabel selfcompassion ditinjau dari jenis kelamin tidak terdapat perbedaan tingkat self-compassion antara remaja perempuan dan laki-laki.

\section{Daftar Pustaka}

Allen, A., dan Leary, M. R. (2010). Self Compassion, Stress, and Coping. Social and Personality Psychology Compass. 4(2), 107-118.

Berk, L. E. (2012). Development Through The Lifespan: Dari Prenatal Sampai Remaja (Transisi Menjelang Dewasa). Yogyakarta: Pustaka Pelajar.

Betts, J., Gullone, E., dan Allen, S. (2009) An Examination Of Emotion Regulation,Temperament, and Parenting Style As PotentialPredictors OfAdolescent Depression Risk Status:A Correlational Study. British Journal of Developmental Psychology, 27, 473485.

Diedrich, A., Grant, M., Hofmann, S. G., Hiller, W., dan Berking, M. (2014). Selfcompassion As AnEmotion Regulation Strategy in Major Depressive Disorder. Behaviour Research and Therapy,58, 43-51. 
Estefan, G., dan Wijaya, Y. D. (2014). Gambaran Proses Regulasi Emosi Pada Pelaku Self Injury. Jurnal Psikologi. Vol 12 No 1, 26-33.

Finlay-Jones, A. (2017). The Relevance Of Self-Compassion As An Intervention Target In Mood and Anxiety Disorders: A Narrative Review Based On AnEmotion Regulation Framework. Clinical Psychologist, 21, 90-103.

Geriadi, M. (2017). Hubungan Antara Regulasi Emosi dengan Perasaan Putus Cinta pada Remaja Kelas 3 di SMA 3 Salatiga. Skripsi. Salatiga: Fakultas Psikologi Universitas Kristen Satya Wacana.

Germer, C.K. (2009). The Mindfull Path to SelfCompassion: Freeing Yourself From Destructive Thoughts and Emotions. The Guilford Press: London

Gilbert, P., dan Procter, S. (2006). Compassionate Mind TrainingFor People With High Shame And SelfCriticism: OverviewAnd Pilot Study Of A Group Therapy Approach. Clinical Psychology and Psychotherapy, 13, 353-379.

Gratz, K. L., dan Roemer, L. (2004). Multidimensional Assessment of Emotion Regulation and Dysregulation: Development, Factor Structure, and Initial Validation of the Difficultiesin Emotion Regulation Scale. Journal of Psychopathology and Behavioral Assessment, 26, 41-54.

Gratz, K. L., dan Roemer, L. (2008). The Relationship Between Emotion Dysregulation andDeliberate Self-Harm Among FemaleUndergraduate Students at an UrbanCommuter University. Cognitive Behaviour Therapy. Vol 37, No $1,14-25$.

Gross, J. J. (1998). The Emerging Field of Emotion Regulation: An Integrative Review. Review of General Psychology, 2, 271-299.

Gross, J. J. dan John, O. P. (2003).Individual Differences in Two Emotion Regulation Processes Implications for Affect Relatonships, and Wel-Being.Journal of Personality and Social Psychology. 85( 2), 348-362.

Gross, J.J., dan Thompson, R.A. (2007). Emotion Regulation: Conceptual
Foundations. In Gross, J.J. (Eds). In J. J. Gross (Ed.), Handbook of Emotion Regulation (pp. 3-24). New York .

Gross, J., Richards. M., dan John, O. P. (2006). Emotion Regulation in Everyday Life. Diakses 2 Februari 2018 dari http://media.rickhanson.net/Papers/ EmotRegDaily\%20Life.pdf

Gyurak, A., Gross, J, J., dan Etkin, A. (2011). Explicit and Implicit Emotion Regulation: A Dual-Process Framework. Cognition and Emotion. USA: Published Psychology Press. Vol .25 No.3, 400412.

Hasan, A. B. (2006). Psikologi Perkembangan Islami: Menyingkap Rentang Kehidupan Manusia dari Prakelahiran hingga Pascakematian. Jakarta: PT RajaGrafindo Persada.

Hurlock, E.B. (2011).PsikologiPerkembangan: Suatu Pendekatan Sepanjang Rentang Kehidupan. Jakarta: Erlangga.

Hwang, J. (2006). A Processing Model ofEmotion Regulation: Insights fromThe Attachment System. Disertation. George State University: College ofArts and Sciences.

Lewis, M., Jones, J, H., Barret, L, F. (2008). Handbook of Emotion Third Edition. New York: Published Guilford Press.

Matsumoto, D., Takeuchi, S., Andayani, S., Kouznetsova, N., dan Krupp, D. (1998). The Contribution of Individualism vs. Collectivism to Crossnational Differences in Display Rules. Asian Journal ofSocial Psychology, 1, 147165.

Neff, K. D. (2003). Self-compassion: An Alternative Conceptualization of A Healthy Attitude Toward Oneself. Self and Identity, 2, 85-101.

Neff, K. D. (2003). The Development and Validation of A Scale to Measure SelfCompassion. Self and Identity, 2,223250.

Neff, K. D. (2012). The Science of Selfcompassion. In C. Germer \& R. Siegel (Eds.), Compassion and Wisdom in Psychotherapy (pp. 79-92). New York: Guilford Press.

Neff, K. D., dan McGehee, P. (2010). Selfcompassion and Psychological Resilience Among Adolescent and 
Young Adults. Self and Identity, 9, 225240.

Neff, K. D., Pisitsungkagarn, K., Hsieh, Y. (2008). Self-Compassion and SelfConstrual in the United States, Thailand, and Taiwan. Journal of Cross-Cultural Psychology. Vol. 39 No. 3, 267-285

Putri, D. W. L., Uyun, Q., dan Sulistyarini, I. (2017).Pelatihan Regulasi Emosi untuk Meningkatkan Kesejahteraan Subjektif Orang dengan Hipertensi Esensial. Philantrophy Journal of Psychology, 1, 1-16

Santrock, J.W. (2007). Remaja Edisi kesebelas Jilid 1. Jakarta: Erlangga

Seppala, E. (2013). Social Connection and Compassion: Important Predictors of Health and Well-Being.Socias/ Research: An International Quarterly, Vol. 80, No.2, 411-430.

Septiyani, D. A., dan Novitasari, R. (2017). Peran Self-Compassion Terhadap Kecerdasan Emosi Pada Remaja Tunadaksa. Indigenous Journal. Vol 2 No. 1, 67-76.

Simon, R. W., dan Nath, L. E. (2004). Gender and Emotion in The United States: Do Men and Women Differ in Self-reports of Feelings and Expressive Behavior? American Journal of Sociology, 109, 1137-1176.

Sirois, F. M., Kitner, R., dan Hirsch, J.K. (2015). Self-Compassion, Affect, and Health-Promoting Behaviors. Health Psychology, Vol. 34, No. 6, 661-669.

Stuntzner, S. (2014). Compassion and Selfcompassion: Exploration of Utility as Potential Components of the Rehabilitation Counseling Profession. Journal of Applied Rehabilittion Counseling.45(10, 37-44.

Sugiyono. (2016). Metode Penelitian Kuantitatif Kualitatif dan R\&D. Bandung: Alfabeta.

Thompson, R.A. (1994). Emotion Regulation: A Theme in Search of Definition. Monographs of the Society for Research in Child Development, 59, 25-52.

Ubaidillah. (2014). Hubungan antara Regulasi Emosi dan Pengambilan Keputusan dalam Melakukan Transaksi di Pasar Valuta Asing pada Trader. Skripsi. Yogyakarta: Fakultas IImu Sosial dan
Humaniora UIN Sunan Kalijaga.

Yarnell, L. M.,Stafford, R. E., Neff, K. D., Reilly, E. D., Knox, M. C., dan Mullarkey, M. (2015). Meta-analysis of Gender Differences in Self-compassion. Self and Identity. Washington DC: University of Southern California. Vol 14 No.5, 499-520.

Yuniar, D., \& Darmawati, I. (2017). Dukungan Keluarga Berhubungan dengan Kecerdasan Emosional Remaja. Jurnal Keperawatan Komprehensif., 3(1),. 9-17. 